\title{
PERAN KOHERENSI TERHADAP KELENTINGAN KELUARGA YANG MEMILIKI ANAK DENGAN SPEKTRUM AUTISTIK (ASA)
}

\author{
Fachrun Naja Maulidia, Melok Roro Kinanthi*), Nurindah Fitria, Atari Suci Permata
}

Fakultas Psikologi Universitas YARSI, Jakarta 10510, Indonesia

*)Email:melok.roro@yarsi.ac.id

\begin{abstract}
Abstrak
Keluarga dengan Anak Spektrum Autistik (ASA) mengalami sejumlah tantangan dalam kehidupan, baik secara fisik, psikologis maupun sosial. Keluarga yang dapat beradaptasi secara efektif akan dapat berfungsi dengan baik dan sejahtera. Bukan hanya sekedar "bertahan", bahkan dapat mengambil manfaat positif dari kesulitan yang dihadapi. Penelitian ini bertujuan untuk menganalisis peran koherensi keluarga terhadap resiliensi keluarga yang memiliki anak dengan spektrum autistik ditinjau dari perspektif ibu sebagai pengasuh utama. Selain itu, penelitian ini juga bertujuan untuk mengetahui perbedaan tingkat koherensi dan resiliensi keluarga ASA ditinjau dari jumlah anak, usia anak, usia responden (ibu), jumlah pengeluaran, suku, pendidikan terakhir, dan lama diagnosis ASA. Penelitian ini dilakukan dengan pendekatan kuantitatif dan desain asosiatif terhadap 148 ibu di wilayah Jabodetabek yang memiliki ASA. Data diperoleh melalui instrumen penelitian yang berbentuk kuesioner, yakni Walsh Family Resilience Questionairre dan The Family Sense of Coherence Scale. Kuesioner tersebut didistribusikan kepada responden penelitian, melalui mediator yayasan atau sekolah anak autistik yang menaungi para responden penelitian tersebut. Data yang telah didapatkan kemudian dianalisis dengan menggunakan analisis regresi sederhana. Hasil penelitian menunjukkan koherensi keluarga memiliki pengaruh yang positif dan berperan secara siginifkan terhadap resiliensi keluarga responden penelitian ini. Hasil penelitian ini mengindikasikan bahwa konsep koherensi keluarga dapat membantu memahami bagaimana suatu keluarga dapat menjadi resilien saat menghadapi situasi sulit.
\end{abstract}

Kata kunci: koherensi keluarga, kelentingan keluarga, spektrum autistik, stres

\section{The Role of Family Sense of Coherence on Family Resilience of Families of Children with Autism Spectrum Disorder (ASD)}

\begin{abstract}
Families of children with autism spectrum disorder experience a number of challenges in life, both physically, psychologically and socially. Families who can adapt effectively will be functioning well and prosper. They are not only survived, but also able to gain some positive benefits from the difficult situations. The purpose of this study was to analyze the role of family sense of coherence on family resilience among Families of children with autism spectrum disorder, based on mother's perspective as the primary caregiver. This study also wants to identify the difference of family sense of coherence and family resilience level based on several demographic factors such as the number of children, the age of Autistic children, the age of participant (mother), the amount of family expenditure, level of education, and length of diagnosis. Using quantitative approach with associative design, subjects in this research are 148 mothers who have a child with autism, living in Jabodetabek area. Data were obtained through questionnaire-based research instruments, which is Walsh Family Resilience Questionnaire and The Family Sense of Coherence Scale. The questionnaires were distributed to research participants through foundation or school concerned in autistic children. The data have been obtained and then analyzed by simple regression analysis. The result indicated that family sense of coherence has a positive and significant correlation between family resilience. It is indicated that family sense of coherence can help us to understand how a family becomes resilient when facing a difficult situation.
\end{abstract}

Keywords: autism spectrum, family resilience, family sense of coherence, stress

\section{PENDAHULUAN}

Data yang dirilis beberapa waktu lalu memperkirakan terdapat 139 ribu Anak dengan Spektrum Autistik (selanjutnya disingkat ASA) dari 400 ribu anak berkebutuhan khusus di Indonesia (Okezone.com, 2 April 2015). Kondisi spektrum autistik dapat membuat anak sulit membentuk relasi sosial atau mengembangkan pola komunikasi yang normal. Tidak hanya itu, Anak Spektrum Autistik (ASA) cenderung menunjukkantidak mampu mengekspresikan perasaan dan pikirannya secara verbal (Muniroh, 2010). Selain itu, ASA juga terobsesi dengan minat dan aktivitas yang bersifat repetitif (Baron- 
Cohen \& Bolton, 1993, diacu dalam Marchant, 2006).

Kondisi ASA memberikan sejumlah implikasi kepada dinamika keluarga (Misquiatti et al., 2015). Keluarga harus mengubah irama kehidupan sehari-hari untuk mengakomodasi kebutuhan ASA (Eiser, 1998, diacu dalam Brody \& Simmons, 2007; Misquiatti et al., 2015; Bashir et al., 2014). Keluarga juga perlu mengupayakan adanya pendampingan atau orang yang dapat membantu merawat ASA (Greeff \& Van Der Walt, 2010). Keluarga yang memiliki ASA cenderung sulit menerima diagnosa spektrum autistik, menyangkal, merasakan ketakutan (Sullivan, 2003) serta memiliki tingkat stres yang tinggi dengan kualitas hidup yang rendah (Zablotsky et al., 2013, diacu dalam Misquiatti et al., 2015). Orang tua dengan ASA cenderung merasa tertekan akibat adanya tanggung jawab pengasuhan (Kusumastuti, 2014). Secara khusus, ibu dengan ASA mengalami tingkat stres yang lebih tinggi dibandingkan dengan ibu dari anak yang mengalami gangguan perkembangan lainnya (Emerson, 2003; Neece \& Baker, 2008, diacu dalam Wang, Michaels, \& Day, 2011). Kehadiran ASA juga membawa dampak terhadap relasi saudara kandung (Bashir et al., 2014). Sebagai pengasuh utama, keluarga memainkan peran penting dalam menjaga kesehatan mental ASA (Lester et al., 2013).

Beberapa literatur menunjukkan adanya tekanan pada keluarga ASA, namun ternyata ada pula keluarga ASA yang dapat tetap kuat dan berdaya dengan kondisi tersebut (Sullivan, 2003). Sebagai contoh, terdapat orang tua ASA yang lebih dapat menerima kondisi anaknya sehingga tidak terlalu merasakan stres, lebih sejahtera (Schweigert, 2011) serta memiliki tingkat keputusasaan rendah (Vetrayan et al., 2013). Sebaliknya, ada pula keluarga yang kurang dapat berlaku adaptif terkait kondisi ASA, seperti tidak menyediakan dukungan sosial bagi ibu yang merawat ASA (Milyawati \& Hastuti, 2009).

Adanya keberagaman kondisi keluarga ASA, menunjukkan bahwa terdapat perbedaan cara menyesuaikan diri dengan situasi sulit atau krisis pada setiap keluarga (Schweigert, 2011). Selain itu, kemampuan penyesuaian diri keluarga ketika mengalami tekanan akan menentukan keberfungsian dan kesejahteraan keluarga di masa selanjutnya (Finkelstein, 2016). Kemampuan keluarga ini disebut keluarga yang lenting/ resilience. Konsep kelentingan keluarga menjadi strategis karena bukan saja berperan dalam keberfungsian dan penyesuaian diri orang tua untuk mampu bersosialisasi dengan lingkungan sekitar dalam mengasuh anak (Nainggolan, 2016), penyesuaian terhadap masalah yang baik tergantung pada tingkat stres dari kondisi yang dialami dan kemudian menantukan strategi yang tepat dengan kondisi tersebut (Oktarina, Krisnatuti, \& Muflikhati, 2015) namun juga membantu mengenali sumber daya yang tepat dalam proses penyelesaian masalah (Lerner \& Kline, 2006, diacu dalam Mahabbati, 2009). Sistem keyakinan keluarga merupakan inti dari semua keberfungsian keluarga dan merupakan dorongan terbentukannya kelentingan (Walsh, 2006). Tanpa modal daya kelentingan maka keluarga akan mengalami kesulitan untuk mencapai proses koping yang adaptif seperti adaptasi, penyesuaian, dan perkembangan keluarga ke arah yang lebih positif (Herbst, Coetzee \& Visser, 2007; Lidanial, 2014; Apostelina, 2012).

Kajian kelentingan keluarga pada keluarga ASA memungkinkan untuk mengidentifikasikan kekuatan dan keberdayaan keluarga serta faktor pendukungnya. Hasil penelitian menunjukkan terdapat korelasi positif antara kelentingan pengasuh dengan perawatan positif yang dilakukan pengasuh terhadap individu yang dirawatnya (Hayas, Arroyabe, \& Calvete, 2015). Selain itu, perspektif kelentingan keluarga memungkinkan peneliti dan praktisi untuk mempertimbangkan kekuatan dan kelemahan sebuah keluarga sebagai suatu sistem, mengingat penggunaan perspektif resiliensi keluarga juga mengindikasikan adanya perubahan paradigma dari sudut pandang yang berfokus pada pendekatan patogenik menjadi pendekatan salutogenik (Greeff \& Wentworth, 2009).

Penelitian tentang spektrum autistik di Indonesia yang diarahkan pada kelentingan keluarga masih sedikit. Penelitian yang sudah dilakukan umumnya berfokus pada dinamika kondisi psikologis dari anggota keluarga tertentu, seperti orang tua atau anak (Kusumastuti, 2014; Bashir et al., 2014; Sa'diyah, 2016), dan juga peningkatan keterampilan terkait metode pengasuhan atau terapi dan intervensi (Boham, 2013; Farida, 2015; Pamungkas, 2015; Rahayu, 2014). Hasil penelitian mengenai kelentingan keluarga pada keluarga ASA baru dilakukan oleh Apostelina (2012). Meski demikian, Apostelina (2012) mengkaji lebih jauh mengenai faktorfaktor yang berkontribusi terhadap pembentukan keluarga yang lenting. 
Menurut McCubbin et al. (2002), kelentingan keluarga merupakan pola perilaku positif dan kemampuan fungsional yang ditampilkan individu atau keluarga dalam situasi sulit atau menekan, yang menentukan kemampuan keluarga untuk kembali dan bertahan untuk mencapai kesatuan dengan tetap mempertahankan dan memperbaiki kesejahteraan anggota keluarga dan unit keluarga secara keseluruhan. Kelentingan keluarga terbentuk ketika keluarga dapat kembali, mempertahankan, atau mencapai keberfungsian yang kompeten setelah situasi sulit terjadi (Van Schoors et al., 2015). Kelentingan keluarga bukan hanya sebuah kemampuan mengatasi dan menjaga kestabilan dalam situasi sulit, akan tetapi juga menggunakan kesulitan untuk mengembangkan dan mengoptimalkan diri. Kelentingan keluarga melibatkan interaksi antara faktor protektif dengan faktor resiko (Bayat, 2007).

Terdapat sejumlah faktor yang berkorelasi dan/atau berpengaruh terhadap kelentingan keluarga, yaitu harapan (Iriani \& Syafiq, 2017)), koherensi keluarga (Coyle, 2005), dukungan sosial (Greef \& Van Der Walt, 2010), strategi koping (Greef \& Van Der Walt, 2010), kelekatan keluarga (Pandanwati \& Suprapti, 2013), komunikasi dalam keluarga (Pandanwati \& Suprapti, 2013; Leone, Dorstyn, \& Ward, 2016; Greef \& Van Der Walt, 2010; Walsh, 2003), sistem keyakinan keluarga, pola organisasi (Leone, Dorstyn, \& Ward, 2016; Walsh, 2003), dan sense of coherence (Walsh, 2002). Sejumlah faktor demografi juga memiliki korelasi dengan kelentingan keluarga, diantaranya sumber daya ekonomi atau penghasilan keluarga (Greef \& Van Der Walt, 2010), status pernikahan (Conger \& Conger, 2002, diacu dalam Lennon \& Heaman, 2015), dan tingkat pendidikan (Benzies \& Mychasiuk, 2009, diacu dalam Lennon \& Heaman, 2015). Diantara berbagai faktor tersebut, peneliti akan berfokus pada koherensi keluarga sebagai faktor yang diduga berperan secara signifikan terhadap resiliensi keluarga pada keluarga ASA. Koherensi keluarga merupakan konsep yang berakar dari pandangan salutogenesis yang mengandung aspek afektif, kognitif, maupun perilaku sehingga dianggap komprehensif dalam menilai cara individu menghadapi situasi yang dialami.

Konsep koherensi keluarga pada dasarnya merupakan sense of coherence yang terdapat dalam sebuah kelompok, dalam hal ini keluarga (Antonovsky \& Sourani, 1988). Adapun yang dimaksud dengan sense of coherence merupakan orientasi menyeluruh yang menunjukkan keyakinan individu yang menetap dan dinamis, mengenai stimulus yang berasal dari lingkungan internal maupun eksternal individu yang bersifat terstruktur, dapat diprediksi, dan dapat dijelaskan; sumber daya yang dibutuhkan untuk menghadapi tuntutan dari lingkungan; dan tuntutan dari lingkungan yang menantang dan berharga (Antonovsky \& Sourani, 1988).

Hipotesis yang diajukan peneliti dalam penelitian ini adalah terdapat peran koherensi keluarga terhadap kelentingan keluarga pada keluarga yang memiliki anak dengan spektrum autistik. Hipotesis peneliti tersebut didasari oleh sejumlah pertimbangan. Pertama, hasil penelitian sebelumnya menunjukkan terdapat korelasi positif yang signifikan antara koherensi keluarga dan kelentingan keluarga, yakni koherensi keluarga yang semakin tinggi akan meningkatkan pula kelentingan keluarga. Kedua, analisis regresi menunjukkan koherensi keluarga memberi sumbangan sebesar 38,8 persen terhadap kelentingan keluarga pada mahasiswa yang berasal dari keluarga miskin (Wandasari, 2012). Ketiga, tingkat sense of coherence yang tinggi memungkinkan keluarga untuk memersepsi potensi tuntutan dari lingkungan sebagai hal yang tidak menekan dan memiliki keyakinan bahwa keluarga akan dapat menghadapi tuntutan tersebut (Antonovsky, 1993, diacu dalam Olsson \& Hwang, 2002). Adanya persepsi ini mengindikasikan bahwa individu atau keluarga yang memiliki sense of coherence akan memiliki pandangan yang cenderung positif terhadap tuntutan atau situasi sulit yang dialami.

Walsh (2002) mengemukakan penilaian kelentingan keluarga dapat dilakukan secara multiperspektif (penilaian dari seluruh anggota keluarga) dan uniperspektif (penilaian dari satu anggota keluarga). Sementara itu, sejumlah penelitian yang melibatkan variabel koherensi keluarga juga dilakukan secara uniperspektif (Moen \& Hall-Lord, 2016; Ngai \& Ngu, 2014). Berdasarkan pemaparan yang telah dikemukakan sebelumnya, penelitian ini bertujuan untuk mengetahui peran koherensi keluarga terhadap kelentingan keluarga pada keluarga ASA, ditinjau dari perspektif ibu.

\section{METODE}

Penelitian ini menggunakan pendekatan kuantitatif dengan desain asosiatif, yakni dengan mengkorelasikan kedua variabel yang diduga memiliki keterkaitan. Selain untuk 
mengetahui peran koherensi terhadap resiliensi keluarga ASA, penelitian ini juga bertujuan untuk mengetahui perbedaan tingkat koherensi dan resiliensi keluarga ASA ditinjau dari jumlah anak, usia anak, usia responden (ibu), jumlah pengeluaran, suku, pendidikan terakhir, dan lama diagnosis ASA.

Pengambilan data di lakukan di wilayah Jabodetabek pada Bulan Januari hingga Februari 2016. Metode pengambilan data dilakukan dengan purposive sampling. Responden yang sesuai dengan karakteristik penelitian diperoleh melalui sekolah anak berkebutuhan khusus untuk ASA, klinik terapi ASA, dan saat penyelenggaraan seminar awam dengan peserta orang tua ASA. Peneliti meminta bantuan gate keeper, yakni staf di tempat-tempat tersebut untuk mendistribusikan instrumen penelitian kepada calon responden. Calon responden yang bersedia berpartisipasi diminta mengisi instrumen penelitian berupa skala lapor-diri (self-report) dan menyerahkannya kepada gate keeper, selanjutnya diserahkan ke peneliti. Dalam penelitian ini, baik kelentingan keluarga maupun koherensi keluarga, akan dilihat berdasarkan uniperspektif (hanya dengan satu anggota keluarga) dengan pertimbangan terbatasnya kesempatan dan sumber daya untuk melibatkan seluruh anggota keluarga. Perspektif yang digunakan dalam menilai kelentingan keluarga dan koherensi keluarga pada penelitian ini adalah perspektif ibu. Hal ini dilandasi oleh pemikiran bahwa di Indonesia, ibu dianggap sebagai pengasuh utama dan memiliki posisi pusat dalam sebuah keluarga. Adanya kondisi demikian peneliti menganggap ibu memiliki peluang yang lebih besar untuk mengetahui gambaran keluarga secara keseluruhan dibandingkan anggota keluarga lainnya.

Jumlah responden dalam penelitian ini adalah 148 orang ibu dari ASA, dengan rentang usia ASA 2-20 tahun dan diagnosa ASA ditegakkan oleh dokter atau psikolog. Sebagai data kontrol, peneliti memberikan kuesioner yang berisi isian terkait data demografi/karakteristik responden, diantaranya pertanyaan terkait jumlah anak, usia anak, usia responden (ibu), jumlah pengeluaran, suku bangsa, tingkat pendidikan responden (ibu), dan lamanya diagnosis ditegakkan.

Pengukuran koherensi keluarga menggunakan instrumen The Family Sense of Coherence Scale (FSCS) yang dikembangkan oleh Anotonovsky (1988). Dalam instrumen ini, semakin tinggi skor FSCS yang diperoleh maka semakin tinggi pula tingkat koherensi keluarga pada keluarganya yang dipersepsikan responden. Instrumen FSCS mempunyai 26 pernyataan dengan penilaian menggunakan tujuh rentang skala Likert, yakni penilaian 1 hingga 7 , yang mana1 mengindikasikan kondisi sangat item yang mengandung pernyataan negatif (unfavorable) dan 7 mengindikasikan kondisi sangat (favorable). Uji reliabilitas terhadap FSCS dengan menggunakan teknik Cronbach's alpha menghasilkan koefisien reliabilitas sebesar 0,922 . Adapun pengujian validitas FSCS dengan menggunakan pendekatan validitas konstruk dan teknik corrected item total correlation menghasilkan nilai koefisien korelasi antara 0,053 hingga 0,733. Sementara itu, dalam penelitian ini tingkat kelentingan diukur dengan menggunakan instrumen Walsh Family Resilience Questionairre (WFRQ) yang dikembangkan oleh Walsh (2003). Dalam instrumen ini, semakin tinggi skor WFRQ yang diperoleh maka semakin tinggi pula tingkat kelentingan keluarga yang dipersepsikan responden. WFRQ terdiri dari 32 pernyataan dengan penilaian menggunakan empat rentang skala Likert, yakni sangat setuju, setuju, tidak setuju, dan sangat tidak setuju. Uji reliabilitas terhadap WFRQ dilakukan dengan menggunakan teknik Cronbach's alpha dan diperoleh koefisien reliabilitas sebesar 0,860. Sementara itu, pengujian validitas instrumen dengan menggunakan pendekatan validitas konstruk dan teknik corrected item total correlation menghasilkan nilai koefisien korelasi antara 0,053 hingga 0,534.

Analisis deskriptif untuk menghitung persebaran skor yang diperoleh dari masingmasing variabel. Peneliti juga melakukan uji normalitas dan uji linieritas sebelum melakukan uji hipotesis dengan analisis regresi sederhana. Selain itu, juga dilakukan uji beda dengan menggunakan t-test dan one way annova untuk melihat perbedaan tingkat koherensi keluarga dan kelentingan keluarga ditinjau dari faktor-faktor jumlah anak, usia anak, usia responden (ibu), jumlah pengeluaran keluarga, suku, pendidikan terakhir, dan lama diagnosis.

Adapun kategorisasi skor The Family Sense of Coherence Scale (FSCS) dan Walsh Family Resilience Questionairre (WFRQ) dilakukan dengan menggunakan rumus kategorisasi menurut Azwar (2012). Nilai yang telah terolah, kemudian dianalisis menggunakan indeks 0 100 selanjutnya dikategorikan dengan rumus tersebut menjadi kategori rendah, sedang, dan tinggi sesuai yang tersaji di Tabel 1 . 
Tabel 1 Rumus kategorisasi WFRQ

\begin{tabular}{lc}
\hline \multicolumn{1}{c}{ Kategori } & Rumus Norma \\
\hline Rendah & $x \leq(\mu-1,0 \sigma)$ \\
Sedang & $(\mu-1,0 \sigma)<x \leq(\mu+1,0 \sigma)$ \\
Tinggi & $(\mu+1,0 \sigma) x \leq$ \\
\hline
\end{tabular}

Keterangan: $\mu=$ skor rata-rata; $\sigma=$ standar deviasi

\section{HASIL}

\section{Karakteristik Responden}

Responden penelitian ini berjumlah 148 individu yang merupakan ibu yang memiliki ASA. Usia responden berkisar antara 20 hingga 60 tahun, dengan mayoritas usia $(66,0 \%)$ ada pada rentang 20 hingga 40 tahun. Sebagian besar responden $(96,0 \%)$ masih terikat status pernikahan dan memiliki dua orang anak (43,0\%). Mayoritas responden memiliki ASA dengan usia 2 hingga 10 tahun $(70,0 \%)$ yang telah di diagnosis selama 2 hingga 4 tahun $(40,0 \%)$ dan telah mengikuti terapi kira-kira selama 2 hingga 4 tahun $(44,0 \%)$.

Ditinjau dari jenjang pendidikan, sebagian besar responden memiliki pendidikan menengah (Sekolah Menengah Atas $=53,0 \%$ ), tinggi (Perguruan Tinggi $=37,0 \%$ ), dan hanya 10,0 persen yang memiliki jenjang pendidikan tingkat rendah (Sekolah Dasar dan Sekolah Menengah Pertama 10,0\%). Mayoritas responden merupakan suku Jawa $(32,0 \%)$, Sunda $(8,0 \%)$, Minang $(8,0 \%)$, Betawi $(5,0 \%)$, Campuran $(5,0 \%)$, sementara lainnya menulis 'Indonesia' sebagai sukunya dan ada yang tidak menuliskan jawaban.

\section{Koherensi Keluarga}

Tabel 2 memperlihatkan hasil perhitungan, skor rata-rata koherensi keluarga 50 dan standar deviasi 10. Skor minimum koherensi keluarga adalah 8,89 dan skor maksimal adalah 73,19 . Hasil penelitian menunjukkan mayoritas responden memersepsikan koherensi keluarga yang dimiliki keluarganya berada pada kategorisasi sedang $(76,35 \%)$, ini berarti tiga perempat responden mempersepsikan keluarganya memiliki cara pandang yang cukup baik dalam memahami, memaknai dan mendayagunakan sumber daya saat menghadapi situasi menantang. Ditemukan pula koherensi tinggi $(15,5 \%)$ dan koherensi rendah (8,1\%). Apabila koherensi tinggi dapat memaknai, memersepsikan dan memiliki pandangan untuk mengelola sumber daya yang ada dan mampu menghadapi keadaan krisis di kehidupan, kalau koherensi rendah berarti belum mampu memersepsikan dan mengelola keadaan krisis dengan baik.
Tabel 2 Sebaran responden berdasarkan kategori koherensi keluarga

\begin{tabular}{lcc}
\hline Kategori & $\mathrm{n}$ & $\%$ \\
\hline Rendah (0-40) & 12 & 8,1 \\
Sedang (41-60 & 113 & 76,3 \\
Tinggi (60-100) & 23 & 15,5 \\
\hline Total & 148 & 100,0 \\
\hline
\end{tabular}

\section{Kelentingan Keluarga}

Berdasarkan hasil penghitungan, skor rata-rata dari resiliensi keluarga adalah 50 dan standar deviasi 10. Skor minimum resiliensi keluarga adalah 14,06 dan skor maksimal adalah 79,60. Hasil penelitian memperlihatkan tiga perempat responden $(75,6 \%)$ mempersepsikan resiliensi keluarga yang dimiliki keluarganya terkategori sedang. Hal ini berarti tiga perempat responden memersepsikan keluarganya memiliki kemampuan yang cukup baik dalam menghadapi situasi sulit dan cukup mampu untuk bangkit kembali dari situasi tersebut. Selanjutnya, sebanyak 10,1 persen partisipan memersepsi tingkat resiliensi keluarga dalam kategori rendah, yang berarti partisipan memersepsikan keluarganya kurang memiliki kemampuan untuk menghadapi situasi sulit dan kesulitan untuk bangkit kembali dari situasi tersebut. Adapun 14,2 persen partisipan memersepsi tingkat resiliensi keluarga dalam kategori tinggi, yang berarti partisipan memersepsikan keluarganya memiliki kemampuan yang baik untuk menghadapi situasi sulit dan bangkit kembali dari situasi tersebut. Kelentingan pada keluarga ASA dibutuhkan untuk tetap menjaga keberfungsian dan ketahanan keluarga (Tabel 3).

\section{Uji Normalitas dan Uji Linieritas}

Uji Kolomogorov-smirnov, hasil uji normalitas menunjukkan bahwa data yang akan diolah dalam penelitian ini terdistribusi normal karena nilai signifikasi $(p)$ nilai signifikansi koherensi keluarga dengan resiliensi keluarga adalah $0,951$ ( $p>0,05)$. Sementara itu dalam uji linieritas diperoleh hasil $p=0,000$ yang berarti terdapat hubungan yang linier antara koherensi keluarga dan kelentingan keluarga karena $p<0,05$ (Gani \& Amalia, 2015).

Tabel 3 Sebaran responden berdasarkan kategori resiliensi keluarga

\begin{tabular}{lcc}
\hline \multicolumn{1}{c}{ Kategori } & $\mathrm{n}$ & $\%$ \\
\hline Rendah (0-40) & 15 & 10,1 \\
Sedang (41-60) & 112 & 75,6 \\
Tinggi $(60-100)$ & 21 & 14,2 \\
\hline Total & 148 & 100,0 \\
\hline
\end{tabular}




\begin{tabular}{|c|c|c|c|}
\hline abel 4 & $\begin{array}{l}\text { Analisis } \\
\text { responden } \\
\text { keluarga }\end{array}$ & $\begin{array}{r}\text { keterkaitan } \\
\text { dengan }\end{array}$ & $\begin{array}{r}\text { karakteristik } \\
\text { koherens }\end{array}$ \\
\hline & Variabel & $\mathrm{F}$ & Sig \\
\hline Jumlah & Anak & 0,970 & 0,426 \\
\hline Usia An & & 0,741 & 0,479 \\
\hline Usia lbu & & 1,746 & 0,188 \\
\hline \multicolumn{4}{|c|}{ Jumlah Pengeluaran } \\
\hline keluarga & & 0,186 & 0,945 \\
\hline Suku & & 0,537 & 0,805 \\
\hline Pendidil & kan Terakhir & 4,720 & 0,010 \\
\hline Lama D & iagnosis & 3,564 & 0,031 \\
\hline
\end{tabular}

Analisis Regresi antara Variabel Koherensi Keluarga dengan Variabel Kelentingan Keluarga

Berdasarkan hasil uji regresi, koefisien determinasi yang didapatkan ( $R$ square) adalah 0,172 atau 17,2 persen, yang artinya besar pengaruh koherensi keluarga terhadap kelentingan keluarga adalah 17,2 persen, sedangkan 82,8 persen dipengaruhi variabel lain diluar penelitian ini. Konstanta (a) yang diperoleh berdasarkan hasil hitung uji regresi adalah 29,240, yang berarti jika tidak ada koherensi keluarga maka resiliensi keluarga mencapai 29,240. koherensi keluarga berperan signifikan terhadap resiliensi keluarga pada keluarga yang memiliki anak dengan spektrum autistik ( $F=30,410 p=0,000)$.

\section{Analisis Keterkaitan antara Karakteristik Responden dengan Koherensi Keluarga}

Analisis independent sample $t$ testdan one way anova untuk melihat keterkaitan antara faktor karakteristik responden dengan koherensi keluarga. Berdasakan Tabel 4, tidak terdapat perbedaan tingkat koherensi keluarga ditinjau dari karakteristik responden, yakni dengan usia ibu, jumlah pengeluaran keluarga, dan suku. Sementara itu, terdapat perbedaan tingkat family sense of coherence yang signifikan ditinjau dari tingkat pendidikan responden $(p=0,010<0,05)$ maupun lamanya diagnosis ASA yang dialami anak responden $(p=0,031<0,05)$.

\section{Analisis Keterkaitan antara Karakteristik Responden dengan Resiliensi Keluarga}

Analisis dengan independent sample t test dan one way anova juga dilakukan untuk melihat keterkaitan antara faktor karakteristik responden dengan kelentingan keluarga. Tabel 5 menunjukkan bahwa tidak terdapat perbedaan tingkat kelentingan keluarga ditinjau dari jumlah anak, usia anak, usia ibu, jumlah pengeluaran keluarga, suku, pendidikan terakhir ibu, dan lama diagnosis
Tabel 5 Analisis keterkaitan karakteristik responden dengan resiliensi keluarga

\begin{tabular}{lcc}
\hline Variabel & $\mathrm{F}$ & Sig \\
\hline Jumlah anak & 0,136 & 0,969 \\
Usia anak & 1,257 & 0,288 \\
Usia ibu & 0,008 & 0,927 \\
Jumlah Pengeluaran & 1,047 & 0,385 \\
keluarga & 0,400 & 0,901 \\
Suku & 0,665 & 0,516 \\
Pendidikan terakhir & 2,203 & 0,114 \\
Lama diagnosis
\end{tabular}

\section{PEMBAHASAN}

Hasil penelitian ini membuktikan adanya peran atau kontribusi koherensi keluarga terhadap kelentingan keluarga khususnya pada keluarga dengan ASA. Temuan ini memiliki keselarasan dengan temuan Coyle (2005) bahwa kelentingan keluarga dapat meningkat jika keluarga dapat mengoptimalkan koherensi keluarga Hasil penelitian ini juga mendukung temuan Almedom (2005), yakni koherensi (sense of coherence) merupakan konsep yang terkait dengan kelentingan. Keluarga dengan tingkat koherensi yang kuat dapat beradaptasi dan mengelola dirinya untuk menjadi lebih baik selama dan setelah masa krisis terjadi (Anderson, 1998, diacu dalam Greeff, Vansteenwegen \& Herbiest, 2011), Hasil penelitian ini juga mendukung pendapat Mc Cubbin et al, (1997, diacu dalam Greeff, Vansteenwegen \& Herbiest, 2011), yakni saat terjadi situasi krisis, koherensi keluarga dapat berperan sebagai faktor protektif, yakni sebagai pelindung keluarga dari faktor resiko yang berpotensi hadir dan memaksimalkan kemampuan keluarga dalam menghadapi kondisi krisis. Pada kasus keluarga dengan ASA, seperti pada penelitian ini, koherensi keluarga mampu menjadi salah satu faktor yang menentukan keluarga dalam beradaptasi dengan tekanan yang muncul dalam kehidupan keluarga akibat salah satu anggota keluarga, yaitu salah satu anak, mengalami spektrum autistik.

Hasil penelitian ini mengindikasikan bahwa terdapat dinamika yang memungkinkan koherensi keluarga dapat berkontribusi terhadap kelentingan keluarga pada keluarga yang memiliki ASA. Kontribusi tersebut dapat terjadi antara lain melalui meningkatnya adaptasi serta keberfungsian keluarga (Ngai \& $\mathrm{Ngu}, 2014)$. Kontribusi koherensi keluarga bagi kelentingan keluarga juga dapat terbentuk melalui pemaknaan positif terhadap situasi. Antonovsky dan Sourani (1988) menyebutkan bahwa dalam variabel koherensi keluarga 
terdapat komponen meaningfulness yakni keluarga memaknai setiap situasi dengan positif atau sebagai hal yang menantang.

Apabila dikaitkan dengan hasil utama penelitian ini, ketika keluarga mampu memaknai situasi tekanan akibat salah satu anggota keluarga, yaitu salah satu anak, mengalami spektrum autistik, secara positif atau sebagai hal yang menantang maka hal tersebut akan membantu keluarga untuk mengatasi dan bangkit dari situasi sulit. Pemaknaan positif tersebut melekat dalam belief system yang merupakan faktor berkontribusi dalam pengembangan kelentingan (Sullivan, 2003). Hal ini memiliki kesesuaian dengan teori penilaian kognitif yang dikembangkan oleh Lazarus (1991), yakni individu yang pada penilaian primer menilai situasi sulit yang dihadapinya secara positif, yakni sebagai tantangan (challenge), alih-alih ancaman (threat) atau kerusakan (harm/loss), cenderung melakukan strategi koping yang bersifat aktif yang pada akhirnya dapat membantu keluarga beradaptasi secara efektif dan menjadi lenting.

Koherensi keluarga memungkinkan keluarga untuk dapat mengelola ketegangan, mengidentifikasikan, dan mengelola sumber daya yang akan digunakan untuk menemukan solusi (Eriksson \& Lindstrom, 2006), Kemampuan tersebut dapat membantu sebuah keluarga lebih lenting saat menghadapi situasi sulit. Selain itu, koherensi juga memiliki korelasi yang kuat dengan optimisme serta memiliki korelasi yang negatif dengan keputusasaan dan depresi (Eriksson \& Lindstrom, 2006).

Koherensi keluarga secara umum terkait dengan pemaknaan keluarga secara positif terhadap stimulus dan tuntutan yang datang dari lingkungan serta ketersediaan sumber daya keluarga yang dimiliki (Antonovsky \& Sourani, 1988). Walsh (2003) menyebutkan adanya pandangan atau pemaknaan positif terhadap situasi yang terjadi dapat digunakan keluarga sebagai salah satu sumber daya untuk menghadapi krisis, yang pada akhirnya dapat membuat keluarga beradaptasi dengan baik dan menjadi lenting. Koherensi yang dimiliki oleh keluarga dapat bermanfaat untuk memahami tekanan sebagai suatu hal yang dapat dikelola dengan sumber daya yang ada (Olsson \& Hwang, 2002, diacu dalam Moen \& Hall-Lord, 2016). Adanya pemahaman yang demikian, keluarga cenderung memaknai permasalahan sebagai suatu tantangan yang dapat diatasi bukan sebagai tekanan
(Langeland et al., 2007; Bergh \& Bjork, 2012). Keluarga akan termotivasi untuk menghadapi berbagai situasi sulit dan berusaha untuk mengenali sumber daya di dalam dirinya (Antonovsky \& Sourani, 1988). Hal itu dapat berdampak pada meningkatnya kepuasan hidup, kesejahteraan, dan keberfungsian keluarga yang merupakan karakteristik keluarga yang lenting (Olsson \& Hwang, 2002; Bergh \& Bjork, 2012; Walsh, 2003; Apostelina, 2012, Sebaliknya, koherensi keluarga yang rendah cenderung membuat kehidupan keluarga menjadi tidak bermakna, tidak teroganisir dengan baik, dan cenderung merasa mudah putus asa. Karakteristik yang demikian berkaitan erat dengan karakteristik keluarga yang tidak lenting (Bergh \& Bjork, 2012). Pisula dan Kossakowska (2010) menemukan bahwa koherensi pada orang tua yang memiliki ASA berkorelasi secara positif dengan kendali diri.

Dari hasil penelitian ini diketahui bahwa tiga perempat responden memersepsikan koherensi keluarga berada dalam kategori sedang. Hal ini mengindikasikan bahwa responden menilai keluarganya telah cukup mampu memaknai situasi yang dialaminya (keberadaan dan pengasuhan anak dengan spektrum autistik) secara positif, cukup mampu memahami permasalahan terkait situasi yang sedang dihadapinya, serta memilih strategi koping atau sumber daya yang tepat dalam untuk menghadapi situasi tersebut, meskipun belum dilakukan dengan optimal. Persepsi responden mengenai tingkat koherensi keluarga memiliki keterkaitan dengan persepsi responden terhadap Generalize Resistance Resources (GRRS) yang dimiliki oleh keluarganya. Generalize Resistance Resources (GRRS) merupakan sumber daya yang dimiliki keluarga maupun lingkungan sosial disekitarnya yang lebih luas, yang dapat berupa sumber daya fisik, kognitif, emosi, budaya dan nilai. GRRS dapat digunakan keluarga untuk mengatasi stres akibat situasi yang menekan (Antonovsky, 1987, diacu dalam Lindstrom \& Eriksson, 2005). Adanya GRRS yang memadai, keluarga akan akan dapat memaknai situasi secara lebih positif dan mampu memilih strategi koping yang adaptif. Selain itu, GRRS juga membantu keluarga dalam mempelajari situasi secara lebih realistis dan memudahkan keluarga untuk mengakses layanan kesehatan (Lindstrom \& Eriksson, 2005; Porterfield \& McBride, 2007).

Hasil lain dari penelitian ini menunjukkan bahwa tiga perempat responden memersepsikan kelentingan keluarga di dalam 
keluarganya berada pada kategori sedang. Peneliti menduga hasil tersebut dikarenakan adanya interaksi antara faktor resiko, yaitu stressor akibat gangguan kesehatan pada salah satu anggota keluarga (ASA) dan faktor protektif terkait karakteristik yang dimiliki oleh keluarganya (Bayat, 2007). Analisis lebih lanjut menemukan bahwa sekitar satu persepuluh responden memersepsikan kelentingan keluarga dalam kategori rendah. Hasil tersebut dapat disebabkan karena kegagalan keluarga dalam menyesuaikan diri dan beradaptasi dengan situasi membuat individu kesulitan untuk menghadapi berbagai peristiwa (Herbst, Coetzee \& Visser 2007; Lidanial, 2014). Sementara itu, untuk satu pertujuh responden yang memersepsikan kelentingan keluarga dalam kategori tinggi peneliti menduga bahwa responden tersebut memiliki karakteristik keluarga yang kuat ataupun motivasi internal, seperti self efficacy, Penelitian sebelumnya menunjukkan bahwa ibu yang percaya diri terhadap kemampuannya dalam mengasuh anak autistik akan berdampak pada ketahanannya dalam menghadapi berbagai situasi (Walsh, 2006)

Hasil penelitian ini menunjukkan tidak terdapat perbedaan tingkat koherensi keluarga ditinjau dari karakteristik responden, yakni dengan usia anak, usia ibu, jumlah pengeluaran keluarga, dan suku, Hasil penelitian tersebut memiliki kesesuaian dengan hasil penelitian sebelumnya yang menyatakan bahwa tidak terdapat hubungan antara variabel demografi yakni usia anak, usia ibu, status sosial ekonomi, dan suku dengan tingkat koherensi di dalam keluarga (Marsh et al., 2007; Ollson \& Hwang, 2002; Pisula \& Kossakowska, 2010).

Hasil penelitian ini juga menemukan perbedaan antara skor koherensi keluarga antara responden yang memiliki tingkat pendidikan rendah dengan tingkat pendidikan tinggi. Tingkat pendidikan yang rendah cenderung membuat individu berada dalam tingkat ekonomi yang rendah pula dan karenanya mengalami kesulitan untuk mengakses layanan kesehatan dan memperoleh pengetahuan tentang kondisi anaknya (Porterfield \& McBride, 2007). Individu dengan pendidikan rendah tetap mampu mencari dukungan sosial dari lingkungan sosialnya dan hal tersebut dapat mengurangi tingkat stres serta membantu perasaan emosional yang dialami keluarga. Dukungan sosial tersebut dapat digunakan individu sebagai sumber daya untuk mengatasi situasi sulit yang dialaminya. Adanya dukungan sosial itu, keluarga dapat memandang situasi dengan cara yang lebih positif karena meyakini dapat menggunakan sumber daya berupa dukungan sosial tersebut sebagai coping. Strategi koping fokus pada emosi dapat menurunkan tingkat stres, strategi yang dilakukan adalah dalam penataan emosi diri terhadap masalah yang dihadapi baik dari berbagai lingkungan disekitar dengan cara mengontrol diri dan menciptakan penilaian positif (Oktarina, Krisnatuti, \& Muflikhati, 2015).

Hasil lain yang diperoleh penelitian ini adalah tidak ditemukannya perbedaan skor koherensi keluarga yang signifikan antara responden pada fase awal diagnosis (0-2 tahun) ASA dan fase diagnosis di atas 5 tahun ( $>5$ tahun) ASA. Hasil tersebut dapat disebabkan karena pada fase awal diagnosis orang tua akan cenderung mencari berbagai macam pengobatan dan dokter yang berbeda untuk menyangkal kondisi anaknya. Perilaku tersebut secara tidak langsung berdampak pada munculnya perasaan optimis dan pandangan positif bahwa kondisi anaknya dapat disembuhkan yang merupakan indikasi dari koherensi keluarga yang baik (Safaria, 2005). Sementara itu, pada fase di atas lima 5 tahun keluarga cenderung telah beradaptasi dan menerima kondisi anaknya yang autistik, sehingga cara pandang yang dimiliki oleh orang tua terhadap kondisi anaknya juga lebih positif dan realistis (Mash \& Wolfe 2005; Muniroh, 2010; Pisula \& Kossakowska, 2010). Menariknya, penelitian ini menemukan adanya perbedaan yang signifikan pada skor koherensi keluarga antara responden dengan lama diagnosis $>5$ tahun dan lama diagnosis 2-4 tahun. Hal tersebut dapat terjadi karena pada fase diagnosis ASA 2-4 tahun, keluarga mulai menyadari kondisi yang dialaminya dan merasakan timbulnya kekecewaan, rasa bersalah, putus asa, frustasi dan kelelahan secara mental akibat tidak adanya perubahan yang terjadi pada kondisi anaknya (Muniroh, 2010). Oleh karena itu, hal ini cenderung menyebabkan rendahnya tingkat koherensi keluarga. Adapun setelah melewati fase diagnosis lebih dari lima tahun, keluarga cenderung telah dapat menerima dan beradaptasi dengan baik sehingga kecenderungan koherensi keluarga menjadi meningkat,

Hasil penelitian ini juga menemukan bahwa tidak terdapat perbedaan tingkat kelentingan keluarga ditinjau dari karakteristik responden, yakni jumlah anak, usia anak, usia ibu, jumlah pengeluaran keluarga, suku bangsa, pendidikan terakhir responden (ibu), dan lama diagnosis. Hal ini menunjukkan bahwa 
kemampuan keluarga untuk menghadapi masalah dan bangkit kembali dari permasalahan tersebut tidak dipengaruhi oleh latar belakang demografi keluarga.

Secara keseluruhan, pengaruh koherensi keluarga yang nyata terhadap kelentingan keluarga yang memiliki ASA menunjukkan peran variabel koherensi dalam menjelaskan kemampuan keluarga mengatasi tekanan yang ditimbulkan. Penelitian ini menegaskan bahwa supporting system yang dibangun di dalam keluarga menjadi faktor penting dalam mendukung kemampuan keluarga mengatasi permasalahan yang ada. Meski demikian, dalam penelitian masih terdapat sejumlah keterbatasan, diantaranya adalah kelentingan keluarga dan koherensi keluarga pada penelitian ini hanya dilihat dari sudut pandang satu anggota keluarga saja, yakni ibu. Hal tersebut dapat menyebabkan gambaran sesungguhnya dari peran koherensi keluarga terhadap resiliensi keluarga menjadi tidak utuh karena tidak melibatkan seluruh anggota keluarga. Sementara itu, keterbatasan lain dalam penelitian ini adalah pengambilan data yang melibatkan pihak kedua tanpa bertemu langsung dengan narasumber. Hal itu memungkinkan peluang error pada penelitian yang disebabkan kurang pahamnya responden terhadap instruksi pada instrumen penelitian menjadi lebih tinggi.

\section{SIMPULAN DAN SARAN}

Temuan utama penelitian ini adalah terdapat peran atau kontribusi koherensi keluarga terhadap kelentingan keluarga pada keluarga yang memiliki Anak Spektrum Autistik ASA). Hasil penelitian ini mengindikasikan bahwa konsep koherensi keluarga dapat membantu memahami suatu keluarga dapat menjadi lenting saat menghadapi situasi sulit. Terkait dengan hal ini, upaya mengingkatkan kelentingan keluarga saat krisis terjadi dapat dilakukan dengan cara membantu keluarga untuk memiliki keyakinan positif mengenai situasi yang dihadapi, termasuk perasaan berdaya dan kemampuan mengelola sumber daya yang ada untuk mengatasi situasi.

Penelitian ini menggarisbawahi signifikansi koherensi keluarga dan kelentingan keluarga pada keluarga yang memiliki ASA. Selanjutnya penting untuk memetakan tingkat koherensi keluarga dan kelentingan keluarga yang dimiliki oleh keluarga berkebutuhan khusus, sehingga dapat dijadikan langkah intervensi selanjutnya.
Selain itu, hasil penelitian ini menekankan perlunya upaya untuk mengembangkan dan melatih koherensi keluarga dan kelentingan keluarga pada keluarga dengan anak berkebutuhan khusus melalui program pemberdayaan keluarga yang diinisiasi dan dirancang oleh lembaga atau instansi terkait seperti lembaga yang melindungi atau mendampingi keluarga dengan anak berkebutuhan khusus, konselor, atau instansi pemerintah terkait. Para pendamping atau konselor keluarga berkebutuhan khusus perlu menggunakan perspektif koherensi keluarga dan kelentingan keluarga saat melakukan pendampingan atau konseling. Perspektif koherensi keluarga dan kelentingan keluarga dapat membantu konselor untuk mengarahkan proses konseling untuk lebih berfokus pada hal-hal positif dan sumber daya yang dimiliki klien sebagai modal yang dapat digunakan untuk beradaptasi dan mengelola situasi sulit.

Sementara itu, dengan beberapa keterbatasan penelitian yang telah dijelaskan dalam pembahasan, diharapkan penelitian selanjutnya dapat melihat kelentingan keluarga secara utuh dari berbagai sudut pandang anggota keluarga bukan hanya ibu sehingga dinamika yang terjadi di dalam keluarga dapat terlihat dengan lebih akurat dan jelas. Selain itu, penelitian selanjutnya diharapkan untuk melakukan proses pengambilan data secara langsung untuk mengurangi tingkat error penelitian tanpa perantara. Adapun responden dalam penelitian ini adalah ibu yang memiliki ASA yang terdaftar di yayasan atau sekolah berkebutuhan khusus sehingga secara umum anak-anak tersebut telah menerima terapi dan proses pelatihan yang meningkatkan keberfungsian dirinya. Keterlibatan dalam suatu terapi akan memengaruhi kelentingan keluarga sehingga diharapkan penelitian selanjutnya melibatkan keluarga dengan ASA yang belum mengalami proses terapi atau pelatihan. Penelitian selanjutnya juga diharapkan untuk meneliti konstruk kelentingan keluarga dan koherensi keluarga pada konteks yang berbeda, baik terhadap keluarga yang memiliki kerentanan terhadap stres ataupun tidak, misalnya keluarga dual career/dual earner, keluarga dengan penyakit kronis, keluarga dengan orang tua yang bercerai bercerai, maupun keluarga dari orang-orang sukses dalam karir maupun pendidikan.

\section{DAFTAR PUSTAKA}

Almedom, A. M. (2005). Resilience, hardiness, sense of coherence, and posttraumatic growth: all paths leading to "light at the 
end of the tunnel". Journal of Loss and Trauma. 10, 253-265. DOI:10.1080/15325020590928216

Antonovsky, A., \& Sourani, T. (1988). Family sense of coherence and family adaptation. Journal of Marriage and Family. 50, 79-92.

Apostelina, E. (2012). Resiliensi keluarga pada keluarga yang memiliki anak autis Jurnal Penelitian dan Pengukuran Psikologi, 1(1), 164-176

Azwar, S. (2012). Penyusunan skala psikologi. Yogyakarta. ID: Pustaka Pelajar.

Bashir, A., Bashir, U., Lone, A., \& Ahmad, Z. (2014). Challenges faced by family of autistic children. International Journal of Interdiciplinary Research and Innovation. 2(1), 64-68.

Bayat, M. (2007). Evidence of resilience in families of children with autism. Journal of Intellectual Disability Research. 51(9), 702-7014. DOI: $10.1111 / \mathrm{j} .1365-$ 2788.2007.00960.x.

Bergh, I., \& Bjork, M. (2012). Sense of coherence over time for parents with a child diagnosed with cancer, BMC Pediatrics. 12(79), 1-5. DOI: 10.1186/1471-2431-12-79.

Boham, S.E. (2013). Pola komunikasi orang tua dengan anak autis: studi pada orang tua dari anak autis di sekolah luar biasa AGCA Center Pumorow Kelurahan Banjer Manado. Jurnal Acta Diurna, 2(4), 1-18

Brody, A.C., \& Simmons, L.A. (2007). Family resiliency during childhood cancer: The father's perspective, Journal of Pediatric Oncology Nursing. 24(3), 152-165. DOI: $10.1177 / 1043454206298844$.

Coyle, J. (2005). An exploratory study of the nature of family resilience. Proquest Dissertations and Thesis. (UMI:2174146)

Eriksson, M., \& Lindstrom, B. (2006). Antonovsky's sense of coherence scale and the relation with health: a systematic review. Journal of Epidemiology Community Health. 60, 376-381. DOI: 10.1136/jech.2005.041616.

Farida, F. (2015). Bimbingan keluarga dalam membantu anak autis (kehebatan motif keibuan). Konseling Religi. 6(1), 63-88.
Finkelstein, M. (2016). Risk and resilience factors in families under ongoing terror along the life cycle. Contemp Fam Ther, 38, 129-139. DOI: https://doi.org/10.1007/s10591-0159356-4.

Greeff, A. P., Vansteenwegen, A., \& Herbiest, T. (2011). Indicators of family resilience after the death of a child. Omega. 63(4), 343-358. DOI: 10.2190/OM.63.4.c.

Greeff, A.P., \& Van Der Walt, K.J. (2010). Resilience in families with autistic child. Education and Training in Autism and Developmental Disabilities. 45(3), 347355.

Greeff, A.P., \& Wenworth, A. (2009). Resilience in families that have experienced heart-related trauma. Current Psychology. 28, 302-314. DOI: https://doi.org/10.1007/s12144-0099062-1.

Hayas, C.L., Arroyabe, E.L., \& Calvete, E. (2015). Resilience in family caregivers of persons with acquired brain injury. Rehabilitation Psychology. 60(3), 295302. DOI: $10.1037 /$ rep0000040.

Herbst, L., Coetzee, S., \& Visser, D. (2007). Personality, sense of coherence and the coping of working mother.SA Journal of Industrial Psychology. 33(3), 57-67.

Iriani, L. P., Syafiq, M. (2017) Gambaran hope pada seseorang penyandang tunarungu wicara yang berprestasi. Character: Jurnal Psikologi Pendidikan. 4 (3), 1-6

Kinanthi, M. R. (2017). Resiliensi keluarga: Upaya memperkuat ketahanan diri anti narkoba berdasarkan perspektif psikologi keluarga, Makalah dipresentasikan pada Focus Group Discussion Penyusunan Instrumen Ukur Ketahanan Diri Bersih Narkoba. Badan Narkotika Nasional. Jakarta. Indonesia.

Kusumastuti, A. N. (2014). Stres ibu tunggal yang memiliki anak autis. Jurnal Psikologi. 2(7), 54-60.

Langeland, E., Kristoffersen, K., Klopstad, W. A., \& Rokne, B. (2007). Sense of coherence predicts change in life satisfactionamong home-living resident in the community with mental health problems: a 1-year follow up study. Quality of Life Research. 16(6), 939-946, DOI: https://doi.org/10.1007/s11136-0079199-z 
Lazarus, R. S. (1991). Emotion and adaptation. New York. USA: Oxford University Press.

Lennon, S.L., \& Heaman, M. (2015). Factors associated with family resilience during pregnancy among inner-city women Midwivery. 31, 957-964.DOI: http://dx.doi.org/10.1016/j.midw.2015.05. 007.

Leone, E., Dorstyn, D., \& Ward, L. (2016). Defining resilience in families living with neurodevelopmental disorder: a preliminary examination of Walsh's framework. Journal of Developmental and Physical Disabilities. 28(4), 595-608. DOI:https://doi.org/10.1007/s10882-0169497-x.

Lester, P., Stein, J.A., Saltzman, W., Woodward, K., McDermid, S,W., Milburn, N., Mogil, C., \& Beardsless, W. (2013). Psychology health of military children: longitudinal evaluation of a family centered prevention program to enhance family resilience. Military Medicine. 178(8), 838-845. DOI: 10.7205/MILMED-D-12-00502.

Lidanial. (2014). Problematika yang dihadapi keluarga dari anak dengan intellectual disability (studi etnografi) (Tesis). Universitas Pendidikan Indonesia. Bandung. Indonesia.

Lindstrom, B., \& Eriksson, M. (2005). Salutogenesis, Journal of Epidemiology Community Health, 59, 440-442, DOI: 10.1136/jech.2005.034777

Mahabbati, A. (2009). Penerimaan dan kesiapan pola asuh ibu terhadap anak berkebutuhan khusus. Jurnal Pendidikan Khusus. 5(2), 75-82.

Marchant, P. (2006). Autistic spectrum disorders and Asian children. British Journal of Educational Psychologist. 54(2), 230-244. DOI: 10,1111/j.14678527.2006.00342.x.

Marsh, S. C., Clinkinbeard, S. S., Thomas, R. M., \& Evans, W. (2007). Risk and protective factors predictive of sense of coherence during adolescence. Journal of Health Psychology. 12 (2), 281284.DOI:

https://doi.org/10.1177/13591053070742 58.

Mash \& Wolfe. (2005) Abnormal Child Psychology. 3 rd ed. USA: Thomson Learning Inc.
McCubbin, M., Balling, K., Possin, P., Frierdich, S., \& Byrne, B. (2002) Family resiliency in childhood cancer. Family Relation. 51 (2), 103-111

Milyawati, L., \& Hastuti, D. (2009). Dukungan keluarga, pengetahuan, dan persepsi ibu serta hubungannya dengan strategi koping ibu pada anak dengan gangguan autism spectrum disorder. Jurnal IImu Keluarga dan Konsumen. 2(2), 137-142. DOI:

http://dx.doi.org/10.24156/jikk.2009.2.2.1 37.

Misquiatti, A.R.N., Britto, M.C., Ferreira, F.T.S., \& Assumpcao Jr, F.B. (2015). Family Burden and Childern with Autism Spectrum Disorders: Perspectives of Caregivers. Family Autism. 17(1), 192200, DOI: http://dx.doi.org/10.1590/19820216201520413

Moen, L. O., \& Hall-Lord, M. L. (2016). Reliability and validity of the Norwegian family sense of coherence. Open Journal of Nursing. 6, 1075-1086. DOI:10.4236/ojn.2016.612102

Muniroh, S. M. (2010). Dinamika resiliensi orang tua anak autis. Jurnal Penelitian. 7(2), 1-11.

Nainggolan, J. A. Penyesuaian diri orangtua dan keberfungsian keluarga yang memiliki anak penyandang autisme di Samarinda. eJournal Psikologi, 4 (2), 215-226

Ngai, F. W., \& Ngu, S. F. (2014). Family sense of coherence and family adaptation among childbearing couples Journal of Nursing Scholarship. 46(2), 82-90 DOI: 10.1111/jnu.12045

Okezone.com. (2 April 2015). Autisme di Indonesia semakin meningkat. Diambil dari

http://lifestyle,okezone,com/read/2015/0 4/02/481/1128312/autisme-di-indonesiaterus-meningkat. [Diunduh pada 24 September 2016].

Oktarina, R., Krisnatuti, D., \& Muflikhati, I. (2015) Sumber stress, strategi koping, dan tingkat stress pada buruh perempuan berstatus menikah dan lajang. Jurnal IImu Keluarga dan Konsumen, 8 (3), 133-141, DOI: http://dx.doi.org/10.24156/jikk.2015.8.3 .133

Olsson, B. M., \& Hwang, P. C. (2002). Sense of coherence in parents of children with different developmental disabilities. 
Journal of Intellectual Disability Research. 46(7), 548-559

Pamungkas, A. (2015). Pelatihan keterampilan pengasuhan autis untuk menurunkan stres pengasuhan pada ibu dengan anak autis. Empathy. 3(1), 1-22.

Pandanwati, K. I. S., \& Suprapti, V. (2012). Resiliensi keluarga pada pasangan dewasa madya yang tidak memiliki anak. Jurnal Psikologi Pendidikan dan Perkembangan. 1(3), 1-8.

Pisula, E., \& Kossakowska, Z. (2010). Sense of coherence and coping with stress among mothers and fathers of children with autism. Journal Autism development disorder. 40(12), 1485-1494. Doi: 10,1007/s10803-010-1001-3.

Porterfield, S.L., \& McBride, T.D. (2007). The effect of poverty and caregiver education on perceived need and access to healthservices among children with special health care needs. American Journal of Public Health. 97(2), 323-329. Doi: 10,2105/AJPH,2004,055921.

Rahayu, S.M. (2015). Deteksi dan intervensi dini. Jurnal Pendidikan Anak. 3(1), 420428.

Sa'diyah, S. (2016). Gambaran psychological wellbeing dan stres pengasuhan ibu dengan anak. Makalah dipresentasikan dalam Seminar ASEAN 2 ${ }^{\text {nd }}$ Psychology and Humanity. Universitas Muhammadiyah Malang. Indonesia.

Safaria, T. (2005). Autisme:Pemahaman Baru untuk Hidup Bermakna Bagi Orang Tua. Yogyakarta: Graha IImu

Schweigert, E. K. (2011). Predictor of successful parents adjustment and family functioning in families with autistic children (Disertasi). University of Wisconsin-Madison. Wisconsin. Amerika Serikat.
Sullivan, M. (2003). When life says you can't: creativity and resilience in families with autistic children residing in New Jersey and Ireland (Disertasi). Drew University, New Jersey. Amerika Serikat.

Van Schoors, M., Caes, L., Verhofstadt, L.L., Goubert, L., \& Alderfer, M.A.(2015). Systematic review: family resilience after pediatric cancer diagnosis. Journal of Pediatric Psychology. 40(9), 856-868. Doi: 10,1093/jpepsy/jsv055.

Vetrayan, J., Daud, A., \& Paulraj, J.S.P.V. (2013). Level of hopelessness among parents with autistic children. Indian Journal of Health and Wellbeing. 4(4), 875-878.

Walsh, F. (2002). A family resilience framework: Innovative practice application. Family Relations. 51(2), 130137. Doi: 10,1111/j,1741$3729,2002,00130, x$.

Walsh, F. (2003). Family resilience: a framework for clinical practice, Family Process. 42(1), 1-18 Doi: 10,1111/j,1545-5300,2003,00001,x.

Walsh, F. (2006) Strengthening Family Resilience (2rd Edition). New York. The Guildford Press

Wandasari, W. (2012). Hubungan antara resiliensi keluarga dan koherensi keluarga pada mahasiswa yang berasal dari keluarga miskin (Skripsi).Universitas Indonesia. Depok. Indonesia.

Wang, P., Michaels, C.A., \& Day, M.S. (2011). Stressesand coping strategies of Chinese families with children with autism and other developmental disabilities.J Autism Dev Discord, 41, 783-795. Doi: 10,1007/s10803-0101099-3. 